\title{
Zákány Judit': Az egészségügyi ellátás során bekövetkező károk kompenzációjának lehetőségei Németországban
}

Debreceni Jogi Mühely, 2012. évi (IX. évfolyam) 3. szám (2012. július) 59-68.

\section{Bevezető gondolatok}

Kutatási témám címe: Felelősségi viszonyok az egészségügyi szolgáltatásban. Ennek keretében kiemelten fontosnak érzem, hogy minél több külföldi ország vonatkozó szabályozásával és gyakorlatával megismerkedjek. A külföldi minták ugyanis iránymutatásként szolgálhatnak a magyar rendszer hiányosságainak kiküszöbölésében, így véleményem szerint a hazai problémákkal kapcsolatos megalapozott állásfoglalás feltétele egy széles látókör kiépítése a témakörben. Jelen dolgozatomban a német szabályozást veszem górcső alá. Fontosnak tartom kiemelni, hogy a téma feldolgozását a polgári jogi vonatkozásokra szükítem, így például az orvosi felelősség büntetőjogi vagy fegyelmi vonatkozásai nem képezik e munkám tárgyát. Dolgozatomban vizsgálom, hogyan kerül szabályozásra az orvos-beteg kapcsolat, a felelösség megoszlását az orvos és a kórház között, valamint a felelősség előfeltételeit.

\section{Modellek az egészségügyi ellátás során bekövetkező károk kompenzációjára}

Az egészségügyi ellátás során bekövetkező károkért való felelősség tekintetében két alapvető modellt különíthetünk el, az úgynevezett peres (hagyományos) rendszerek mellett megjelennek a nem peres, más néven adminisztratív (vagy no fault) rendszerek. ${ }^{2}$

Míg a peres rendszerekben jellemzően az adott ország polgári törvénykönyvében található kártérítési jogi szabályokat alkalmazzák, az eljárás bíróság előtt folyik, ${ }^{3}$ addig a nem peres felelősségi rendszerekben külön jogszabályok határozzák meg a kompenzáció rendjét, az eljárás pedig egy külön erre a célra felállított adminisztratív testület előtt történik. ${ }^{4}$ Markáns elkülönítő jegye még a no fault rendszereknek, hogy a cselekmény felróhatóságának vizsgálata nélkül egy speciális ún. baleseti kompenzációs rendszeren keresztül történik a kompenzáció.

Az országok nagy része a hagyományos kategóriához tartozik, míg a no fault rendszert a mintaállamot képező Új-Zéland mellett a Skandináv területeken alkalmazzák. Jelen írás szempontjából fontos kiemelni, hogy a német modell a hagyományos, peres rendszerekhez tartozik, azonban kiemelten fontosnak tartják az alternatív vitarendezés támogatását is. Ennek köszönhetően egy önkéntesen és ingyenesen igénybe vehető előszürő rendszer müködik az orvos-beteg közötti konfliktusok tekintetében, melyet a bírósági eljárást megelőzően lehet igénybe venni. A későbbiekben részletsebben is foglalkozom vele.

\section{A kárfelelősség formái Németországban}

Németországban az egészségügyi szolgáltató és a beteg között fő szabályként szerződéses kapcsolat jön létre. Többféle szerződéstípus alakult ki, melyek eltérően osztják meg a felelősséget az orvos és az egészségügyi intézmény között. Emellett alkalmazhatóak lehetnek a szerződésen kívüli károkozásra vonatkozó szabályok is, ha bárki egy másik egyénnek kárt okoz és felek közt nincs közvetlen szerződéses kapcsolat. Eltérően a francia modelltől ${ }^{5}$ itt lehetséges mindkét szabályrendszerre egyidejűleg keresetet alapítani. Mind a deliktuális mind a kontraktuális felelősség felróhatóságon alapul.

Fontosnak tartom kiemelni, hogy 2002-ben fontos jogszabályi változás történt. Ezt megelőzően nem vagyoni kártérítési igény szerződésszegés esetén nem volt érvényesíthető 
csak a szerződésen kívüli károkozás szabályai körében. Viszont a kontraktuális felelösség körében az elévülési idő jóval meghaladta a deliktuális felelősségnél meghatározott 3 évet. A jogszabály módosítást követően egységesülés figyelhető meg egyrészt az elévülési idő tekintetében, emellett pedig szerződésszegés esetén is lehetővé vált a nem vagyoni kártérítés igénylése személyes sérelem bekövetkezése esetén. Viszont szerződésszegéssel okozott károk esetén bevezetésre került a vétkesség vélelme. ${ }^{6}$

Létezik a károk meghatározott csoportjára az objektív felelősség is, ${ }^{7}$ ahol tehát a felróhatóság nem követelmény, viszont ezen igények vizsgálatánál is megmarad a hagyományos bírósági közeg, itt sem lépünk ki a hagyományos peres modellből.

Ezek mellett pedig egyes károkra vonatkozóan állami felelősség áll fenn. Az alábbiakban a fentebb említett négy felelősségi formát fejtem ki részletesebben.

\subsection{Szerződéses felelősség}

A BGB rendelkezései szerint az egészségügyi szolgáltató és a beteg között fennálló szerződés egy szolgáltatási szerződés, melynek lényege, hogy a szolgáltató nem arra vállal kötelezettséget, hogy egy meghatározott eredményt érjen el, hanem arra, hogy a szerződés tartalmának megfelelően egészségügyi szolgáltatást nyújtson. ${ }^{8}$ Arra, hogy mi minősül megfelelő egészségügyi ellátásnak a felelősségi előfeltételekről szóló fejezetben részletesebben is szólok.

A legáltalánosabb az, hogy a beteg csak a kórházzal köt szerződést, így a kórház lesz felelös, mind az egészségügyi ellátásért, mind az ápolásért mind pedig a hotelszolgáltatásokért is. Így, ha probléma történik az ellátás során, a kórházat perelheti a beteg a köztük létrejövő szerződés megszegéséért.

A következő lehetőség, hogy a beteg amellett, hogy a kórházzal is szerződéses viszonyba kerül, kiegészítő szerződést köt egy orvossal is, kiválasztja őt például egy mütéti beavatkozás elvégzésére. Ebben az esetben az orvos személyes kötelezettséget vállal a beteg ellátására, más személy csak akkor végezheti el a beavatkozást, ha a beteg ebbe kifejezetten beleegyezik. Mivel ebben az esetben a beteg és a kiválasztott orvos között közvetlen szerződéses kapcsolat van, a beteg a nem megfelelő kezelés esetén perelheti az orvost szerződésszegésért. A kórházzal szemben ilyen esetben csak az ápolás vagy hotelszolgáltatás körében megvalósuló szerződésszegő magatartásokért indítható eljárás. ${ }^{10}$

A harmadik lehetőség pedig az, amikor az orvos nem áll munkavégzésre irányuló jogviszonyban a kórházzal, ahol elvégzi a beavatkozást, csupán a kórház által nyújtott infrastruktúrát veszi igénybe a beavatkozás elvégzéséhez. Ilyenkor is külön szerződés van a beteg és az orvos, valamint a beteg és a kórház között is. A kezelés hibáiért itt is az orvos lesz felelős, az ápolás és a hotelszolgáltatás körében pedig a kórház. ${ }^{11}$

\subsection{Szerződésen kívüli felelősség}

Ahogyan korábban is említettem lehetőség van arra, hogy a beteg a szerződésszegéssel okozott kár megtérítésével egyidejüleg a szerződésen kívüli károkozás szerint is igényt érvényesítsen azzal szemben, akivel közvetlen szerződéses jogviszonyban nem áll ugyan, de az őt ért személyes sérelem bekövetkezéséért felelős. A szerződésen kívüli károkozás alapján mindenki felelősséggel tartozik a saját maga által végzett tevékenységéért, hibáiért. Kiegészítő szabály, hogy a felróhatóság, mint a deliktuális felelősség egyik alapfeltételének megállapításánál az is kellő alapot jelenthet, ha valaki a szervezés, alkalmazottak megválasztása, utasítása, felügyelete során követett el hibát. 


\subsection{Objektív felelősség}

Az egészségügyi szolgáltatók felelőssége körében fő szabály a felróhatóságon alapuló felelősség, az ettől független felelősségre vonás csak kivételes esetben lehetséges mind az orvosok, mind pedig a kórházak esetében. Csak abban az esetben alkalmaz a bíróság objektív felelősséget, ha orvostudományi kutatás során, radioaktív anyag alkalmazása folytán okoznak sérelmet a betegnek. ${ }^{12}$

\section{4. Állami felelősség}

Szintén nem bír központi jelentőséggel az állami felelösség, mely akkor jön figyelembe, ha az orvos egy tisztán közjogi jogviszony szereplöjeként látja el a tevékenységét. Ide tartozik például, ha egy büntetöügyben elrendelik egy orvosi vizsgálat elvégzését és ennek során történik visszásság. A kötelező védőoltásokért való felelősség szintén ebbe a körbe tartozik. ${ }^{13}$

\section{Felelősségi viszonyok}

A felelősségi formák vizsgálatát követően egy bonyolult felelősségi viszonyrendszer bontakozik ki előttünk. A következőkben ennek letisztázására törekszem a fent leírtak felesleges megismétlésének elkerülésére törekedve.

A felelősségi szintek alapján láthatjuk, hogy az orvos felelősségét megalapozhatja egyrészt a közte és a beteg között fennálló szerződéses kapcsolat. Amennyiben a beteg kiválaszt egy orvost egy adott beavatkozás elvégzésére akkor a köztük fennálló szerződés következtében az egészségügyi ellátásért az orvos lesz a felelős. Amennyiben nincs az orvos és a beteg közt direkt szerződéses viszony (mert például a páciens csak a kórházzal kötött teljeskörü ellátásra vonatkozó szerződést) az orvos felelősségét az általa végzett kezelés során elkövetett hiba, az ennek következtében a betegnek okozott sérelem is megalapozhatja a szerződésen kívüli kárfelelősség alapján. Emellett az orvos felelösségét az általa igénybe vett közremüködő felróható magatartása is megalapozhatja, amennyiben az orvos maga kérte az illető közremüködését vagy legalább beleegyezett. Végül a vezető beosztású orvosok, főnővérek esetében a felelősség kiterjed az irányításuk alá tartozók megfelelő utasításokkal való ellátására, felügyeletére, munkaszervezési kérdésekre is. ${ }^{14}$

A következő, amit vizsgálunk, magának az intézménynek a felelőssége. Itt is lehetséges, hogy a felelősséget a beteg és az egészségügyi intézmény közötti szerződés alapozza meg. Ritka eset az, hogy a beteget a kórházhoz ne füzze szerződés csak az ellátó orvoshoz, így a felelösség általában a szerződésszegés körében állapítható meg. Láthattuk, hogy amennyiben teljeskörü ellátásra vonatkozóan köt szerződést a páciens az intézménnyel, csak vele áll szerződéses viszonyban, az intézmény lesz felelős minden szolgáltatásért, beleértve az egészségügyi szolgáltatásért is. Viszont az is lehetséges más szerződéstípus esetén, hogy a kórház csak az ápolásért és a hotelszolgáltatásokért felel, az ellátásért pedig az orvos. Szintén felmerülhet szerződésen kívüli károkozásért való felelősség is, melyet a kórház igazgatójának, vezető beosztású munkavállalóinak a magatartása alapozhat meg. Például, a kórház igazgatója felelős azért, hogy megfelelő higiénés viszonyok között, megfelelő állapotú infrastruktúrával dolgozzanak az orvosok. ${ }^{15}$

A felelősségi viszonyok részese a biztosító is, amely az érintett orvos vagy egészségügyi intézmény felelősségbiztosítását látja el. A német jogszabályok alapján az orvosoknak kötelező felelősségbiztosítást kötni, mivel saját felróható magatartásukért személyesen is felelősségre vonhatóak, a kórházakat viszont ilyen kötelezettség nem terheli, számukra ez csak lehetőség. 


\section{Alternatív vitarendezési lehetőségek}

A felelősségi előfeltételek vizsgálatát megelőzően fontosnak tartom, hogy szóljak a korábbiakban már említett, egyfajta előszürő rendszerként müködő alternatív vitarendezési formáról, amit nagyon pozitívnak tartok. Bevezetésképpen néhány általános információt közölnék a peren kívüli vitarendezési modellekröl.

A peren kívüli vitarendezésnek az egészségügyi ellátások tekintetében két alapvető modellje alakult ki. Az egyik az arbitrációs modell, melynek lényege, hogy egy a felek által választott döntőbíró hoz (többségében) végleges döntést ${ }^{16}$ az elé terjesztett vitás ügy tekintetében. Mivel a felek a döntési jogukról teljesen lemondanak és átruházzák azt a választottbíróra, ez a technika nem sorolható be az egyeztető eljárások közé, ${ }^{17}$ sokkal inkább a „hagyományos” bírói út igénybevételével mutat hasonlóságokat. Azonban az arbitrátor nem szakbíró, igen jelentős diszkrecionális jogköre van és köteles a semlegesség és pártatlanság elvét tiszteletben tartva feloldani a felek közötti konfliktust.

A másik vitarendezési modell a mediációs modell. Ennek lényege, hogy egy semleges harmadik fél segítséget nyújt a feleknek vitájuk rendezésére, anélkül azonban, hogy maga döntené el a vitát. Az eljárás informális, békéltető jellegü, célja, hogy segítse a feleket egy kölcsönösen elfogadható egyezség létrehozásában." ${ }^{18}$ Tehát a mediáció egy együttmüködésen alapuló, békés konfliktuskezelési forma, amelyben a felek egyézségre jutását egy pártatlan személy, a mediátor segíti elö. A mediátor feladata abban áll, hogy a problémamegoldó folyamatot kontrollálja, tehát nem bírál, nem értékel, nem dönt a felek közötti jogvitában. A szerepe tehát a felek álláspontjának közelítésében, a felek közötti kapcsolat javításában áll. ${ }^{19}$ Magyarországon a mediációs modell került bevezetésre a törvényi szabályok szerint, azonban sajnálatosan nem kellően preferált és előtérbe helyezett egy ilyen típusú eljárás, holott a perek elkerülése érdekében kívánatos lenne az alternatív vitarendezés sokkal szélesebb körben történő alkalmazása hazánkban is.

A Németországban kiépített vitarendezési mechanizmus viszont szélesebb körben ismert és elterjedt lehetőség a pert megelőzően. Akár önmagában is alkalmas lehet arra, hogy a bírósági utat elkerüljék a felek, ha mindkettejük számára elfogadható döntés születik. Akár azt is segítheti, hogy ha mégis perre kerül sor, köszönhetően annak, hogy egy elözetes, alapos informálódáson már túl vagyunk, rövidebb idő alatt, egyszerübben lezárható az eljárás. A német modellről azt mondhatjuk, hogy az arbitrációs modellhez áll közelebb, viszont teljes mértékben nem azonosítható vele, a döntés itt ugyanis nem kötelező a felekre nézve. A lényege, hogy a német orvosi kamara különböző testületeket müködtet, így egyezséget létrehozó testületeket, szakértői testületeket, illetve vegyes testületeket. Az egyezséget létrehozó testületek az orvos és a beteg közt vitás kérdésekről hoznak döntést, a kártérítési igény jogszerüsége és akár összegszerüsége tekintetében is döntést hozhatnak. A szakértői testületek azzal kapcsolatosan adnak szakértői véleményt, hogy a betegnek nyújtott kezelés megfelelő színvonalúnak tekinthető-e. ${ }^{20}$

Az eljárással kapcsolatosan három fontos alapelvet kell kiemelnünk. Az egyik az önkéntesség elve. Azaz, e vitarendezési mód pusztán egy lehetőség mindkét fél számára, senkit nem lehet arra kényszeríteni, hogy ilyen eljárásban vegyen részt. Így csak akkor kerül sor eljárásra, ha abba mindkét fél beleegyezett.

A másik alapelv az eljárás ingyenessége, ami véleményem szerint nagyon nagy pozitívumként emelhetö ki. ${ }^{21}$

A harmadik alapelv, ami miatt nem tekinthető tisztán arbitrációs modellnek a kiépült mechanizmus, hogy a testületek által meghozott döntés nem kötelező erejü a felekre. Elfogadhatják, de ha nem felel meg bármelyikük számára elkezdődhet a bírósági eljárás. Ahogyan azt korábban is említettem a bíróság elötti eljárást is nagyban könnyítheti, ha 
elözetesen már történt vizsgálat az ügyben, viszont fontos kiemelni azt is, hogy kötőereje nincs a bíróság felé sem a testület döntésének. ${ }^{22}$

A peren kívüli vitarendezés ezen formája kiemelkedően előnyös vonásokkal rendelkezik, melyek az alábbiakban foglalhatók össze. Véleményem szerint a rendszer legnagyobb elönye, hogy ingyenesen adja meg a lehetőséget az orvos-beteg közti viszony rendezésére. Azért tartom fontosnak ezt a lehetőséget, mert Németországban a pereskedés kifejezetten drága, az ügyvédek díja és az eljárás költsége magas. ${ }^{23}$ Azt is fontos kiemelni, hogy komoly szakmai tudással rendelkező személyek által történik meg az eset kivizsgálása jogi és orvosi szemszögből egyaránt. További előnyként említhető, hogy sokkal rövidebb idő alatt zajlik le egy ilyen típusú vizsgálat, mint a peres eljárás. Így ha a felek számára elfogadható a döntés, akkor a beteg előbb jut kompenzációhoz. ${ }^{24} \mathrm{Ha}$ esetleg bírósági út igénybevétele történik, annak az igényérvényesítés idejét sem csorbítja, hisz az elévülési idő nyugszik egy ilyen eljárás időtartama alatt. Összességében pedig azt mondhatjuk, hogy sokkal kevesebb megterhelést, vitát, érdekellentétet generál egy ilyen egyeztető eljárás az orvos és beteg között, mint a peres út, ami nagyon fontos.

\section{A felelősség előfeltételeinek vizsgálata 6.1. A megfelelő színvonalú egészségügyi ellátás követelménye}

Minden egészségügyi ellátással kapcsolatosan támasztott igény általános alapja, hogy a kezelés nem felelt meg az általánosan megkívánt színvonalnak. A betegnek ugyanis minden körülmények között joga van arra, hogy szakszerü kezelést kapjon, amely egy kellö tapasztalattal rendelkező orvos által, az aktuális orvostudományi eredményeket is figyelembe véve nyújtott ellátást jelent. ${ }^{25} \mathrm{Ez}$ utóbbi követelmény úgy vélem igényel némi magyarázatot. Az ellátás akkor nem felel meg ez utóbbi kívánalomnak, ha a kezelés időpontjában már rendelkezésre áll egy újabb, biztonságosabb, az orvostudomány által elfogadott kezelési mód. $\mathrm{Ez}$ nem jelent kötelezettséget arra, hogy minden új orvostudományi eljárást azonnal alkalmazni kellene. ${ }^{26}$ Abban az esetben kell nem megfelelő színvonalúnak, elavultnak tekinteni a régebbi kezelési módot vagy technikai eszközt, ha az új kezelési módot vagy eszközt már megfelelően tesztelték, helybenhagyták, széles körben alkalmazzák, a beteget kevesebb kockázatnak teszi ki, mint a régebbi, illetve a sikeres kezelés esélye az új metódusnak vagy eszköznek köszönhetően jelentősen nagyobb.

\subsection{A felróhatóság vizsgálata}

A felelősség megállapításának fontos előfeltétele, hogy az előbb említett megfelelő ellátási színvonaltól felróható módon eltérjen a kezelést végző orvos. Igaz minden eset egyedi, azonban mégis csoportosíthatjuk, hogy melyek a leggyakrabban előforduló tipikus hibák, melyek a felróhatóság megállapítását eredményezhetik. A következőkben ezeknek a rövid jellemzésére törekszem.

Alapvetően két csoportra oszthatjuk az ellátás során elkövethető, a felróhatóságot megalapozó hibákat. Az egyik csoporthoz tartoznak az ún. kezelési hibák, a másik kategóriát pedig a nem megfelelő tájékoztatásból a tájékozott beleegyezés hiányából eredő visszásságok alkotják. ${ }^{27}$

Az egészségügyi ellátás különböző szakaszaihoz más és más tipikus kezelési hibák társíthatók. Az ellátás első szakasza a beteg kivizsgálása a diagnózis felállítása céljából, mely mindjárt magában is rejti az első hibalehetőséget: a téves diagnózis felállítását. Ilyen esetekben különbséget kell tenni az alapján, hogy az orvos elvégezte a szükséges teszteket és azok értékelése során jutott téves eredményre vagy pedig azért nem megfelelő a diagnózis, mert el sem végezte a szükséges vizsgálatokat. ${ }^{28}$ Amennyiben arról van szó, hogy a szükséges és indokolt vizsgálatok elvégzését követően jut téves eredményre az orvos, a bíróság csak 
alapvető diagnosztikai hiba esetén marasztalja el. Figyelembe veszik ugyanis azt a bizonytalansági tényezőt, mely az orvoslás természetéből és az emberi test kiszámíthatatlanságából fakad. Egyes betegségek ugyanis gyakran nehezen felismerhetők és az is lehetséges, hogy nem tipikus tünetekkel jelentkeznek az adott betegnél. Viszont, ha a hibás diagnózis abból fakad, hogy az orvos nem végezte el az adott tünetegyüttes által megkívánt szükséges vizsgálatokat, egyértelműen kezelési hibáról van szó és a magatartás felróhatónak minősül. ${ }^{29}$

Az ellátás következő szakasza a megfelelő kezelés megválasztása. Az orvos felelősséggel tartozik azért, hogy a rendelkezésre álló lehetőségek közül a legmegfelelőbbet válassza a beteg számára. Ez nem jelent kötelezettséget arra nézve, hogy az opciók közül a legkisebb kockázatút kellene választania. Lehetnek ugyanis olyan esetek, amikor igazolható a kockázatosabb kezelés szükségessége az adott páciens esetén, illetve az is lehetséges, hogy a nagyobb kockázatú terápia alkalmazása esetén sokkal kedvezőbb a beteg gyógyulási esélye.

A következő a kiválasztott kezelés végrehajtása, amivel kapcsolatban kiemelnék egy érdekességet. Felelősséget alapozhat meg az is, ha egy egészségügyi intézmény elvégez egy kockázatos beavatkozást, holott a személyzet képzettsége vagy az eszközök elavultsága indokolttá tenné, hogy a beteget egy másik intézménybe irányítsák. ${ }^{30}$

Ahogyan korábban is említettem, a kezelési hibák mellett a nem megfelelő tájékoztatás is megalapozhatja az ellátó felelősségét. A tájékoztatási kötelezettség az egyén önrendelkezési jogából fakad, ugyani a beteg csak akkor tudja megalapozottan eldönteni, hogy vállalja-e a kezelést, ha megfelelően informálják öt. A beteg rendszerint ugyanis nincs birtokában a betegségekkel, kezelésekkel kapcsolatos ismereteknek, információs aszimmetria jelenik meg, amit ki kell egyenlíteni. Így az orvosnak tájékoztatnia kell a beteget a beavatkozás lehetséges kockázatairól, ${ }^{31}$ a kezelés elmaradásának kockázatairól, illetve arról, hogy milyen mellékhatásokkal, utólagos hatásokkal kell esetlegesen számolnia. Az orvosnak széleskörúen, de nem túlzottan hosszadalmasan, bonyolult módon kell tájékoztatnia a pácienst, hogy megértse mivel jár az adott beavatkozás. ${ }^{32}$ Fontos, hogy a tájékoztatásnak szóban is meg kell történnie, és hogy megfelelö időt kell biztosítani a beteg számára, hogy döntést hozzon. Amennyiben a beteg megfelelően informált és beleegyezik a beavatkozás elvégzésébe akkor a kezelés jogszerü és érvényes. Ha az orvos a beteg tájékozott beleegyezése birtokában megkezdi a kezelést fontos, hogy köteles a beleegyezés keretei között maradni. Ha úgy véli, hogy olyan beavatkozás elvégzése is szükségessé vált, amelyre a páciens beleegyezése nem vonatkozott, akkor meg kell szakítania a kezelést és újabb hozzájárulást kérni. ${ }^{33}$

\subsection{Kár bekövetkezése}

A felelősség megállapításának az eddigieken túl előfeltétele, kimutatható legyen a sérelmet szenvedett személyt ért károsodás. Amennyiben megállapítást nyer, hogy egy személy vagy szervezet kárt okozott, korlátozás nélkül meg kell azt fizetnie a károsult számára. A német jogban is különbséget teszünk vagyoni és nem vagyoni károk között.

A vagyoni károk megállapítása annak vizsgálata alapján történik, hogy milyen helyzetben lenne a károsult abban az esetben, ha nem szenvedte volna el a sérelmet. Azaz, kárpótolni kell öt minden anyagi kárért, amely öt a sérelem következtében érte, olyan helyzetbe kell hozni, mintha az be sem következett volna. ${ }^{34}$ Vagyoni károk körében említhetjük például a gyógykezelés költségeit. Ebbe beletartozik minden szükséges ellátási költség, tekintet nélkül arra, hogy az adott kezelés eredményes volt-e. Vagyoni kárnak tekinthető a jövedelem kiesés is. Ez alatt nemcsak a kezelés ideje alatt elmaradt keresetet értjük, hanem a kialakult fogyatékosság és munkaképesség csökkenés következtében elszenvedett keresetveszteséget is. Ezek mellett pedig egyéb, járulékos költségekre is igényt tarthat a károsult, melyek a sérelem következtébe időszakonként visszatérően jelentkeznek. Így például rehabilitációs kezelések 
gyógyfürdőben, gyógyászati segédeszközök, automata váltó a gépjármübe, fogyatékosság esetén a lakóház akadálymentesítésének költségei. ${ }^{35}$

Nem vagyoni kárnak minősül minden olyan veszteség, mely direkt vagyoncsökkenést nem eredményez ugyan, de olyan személyiségi jogsértés következik be, amely valamilyen fájdalmat, betegséget idéz elö, vagy legalább a károsultat tartósan vagy időlegesen akadályozza életmódjának szabad megválasztásában. Ennek egyik típusa a fájdalomdíj, mely egyrészt a károsult nem vagyoni kárainak megtérítését szolgálja, másrészt elégtételt biztosít számára az őt ért sérelmekért. ${ }^{36}$

Fontosnak tartom kiemelni, hogy annak ellenére, hogy emelkedő tendenciát mutatnak a kártérítési összegek, jóval alacsonyabb szinten maradtak a nem vagyoni kártérítések, mint például az USA-ban. Több okra vezethetjük vissza azt a pozitív vonását a német rendszernek, hogy ezek az összegek nem szaladtak el olyan mértékben, ahogyan az tengeren túli rendszerben láthatjuk. A normalizált keretek közt maradó kártérítések köszönhetőek egyrészt a magas szintü szociális jóléti rendszernek Németországban, a károk egy része ilyen formán is megtérül. Másrészt eljárási okai is vannak. Egyfelől az, hogy szakbírók hozzák a döntést és semmilyen formában nincs jelen a laikus elem a bíróságokon, ráadásul a bírák többé-kevésbé követik az egyes sérelmekkel kapcsolatban kialakult kompenzációs gyakorlatot. ${ }^{37}$ Másrészt egy sajátos eljárási szabály, hogy szankcionálják azt a felperest, akinek a keresete eltúlzott ${ }^{38}$ azzal, hogy nem hárítják át ilyen esetben a pervesztes alperesre a teljes perköltséget, hanem a felperessel megosztva kell kifizetni azt az eltúlzott igény miatt. ${ }^{39}$

\subsection{Okozati összefüggés}

A fenti előfeltételeken túl fontos, hogy az ellátást végző személy jogellenes, felróható magatartása és a bekövetkező kár között fennálljon az okozati összefüggés. Ennek megállapítása több lépcsőben történik. Elsőként nyilván azt vizsgálják, hogy a beteg által elszenvedett sérelem az ellátást végző orvos hibája nélkül is bekövetkezett-e volna. Amennyiben igen, akkor nyilván nincs meg az okozati kapcsolat és a felelösség nem állapítható meg. ${ }^{40}$ Ha viszont az orvos hibája nélkül nem következett volna be a sérelem tovább vizsgálják, hogy melyek a sérelem bekövetkezése szempontjából jelentős cselekvések vagy mulasztások az orvos magatartása körében.

\section{A bizonyítási teher alakulása}

A bizonyítási teher alakulása az egész igényérvényesítés kimenetele szempontjából döntő fontosságú.

A bizonyítási teherrel kapcsolatban fö szabályként azt mondhatjuk, hogy a beteg, mint felperes lesz köteles mindazon tényt és állítást alátámasztani, amin a keresete alapul, és az egészségügyi szolgáltató, mint alperes lesz köteles bizonyítani mindazokat a tényeket és állításokat, amelyek alapján a keresetet el kell utasítani. ${ }^{41}$ A beteg köteles bizonyítani, hogy az orvos a hibát vétett a kezelés során, és ezzel okozati összefüggésben kára keletkezett. Érdekes különbség ez a magyar szabályozáshoz képest, ahol is az exculpatios bizonyítás érvényesül fö szabályként, így az egészségügyi szolgáltatónak kell bizonyítania, hogy a magatartása nem volt jogellenes és nem volt felróható, míg a beteg a kár bekövetkezését és mértékét, illetve az okozati összefüggést köteles bizonyítani. Elképzelhető, hogy a bizonyítási teher ilyen formában történő megosztása eredményezi, hogy igen sok keresetet megalapozatlannak találnak Németországban. ${ }^{42} \mathrm{Ez}$ ugyanis komoly terhet ró a betegre. Fontos kiemelnünk viszont, hogy ez csak a fö szabály, vannak olyan esetek, amikor megfordul a bizonyítási teher és az orvosnak kell azt alátámasztania, hogy ő megfelelően eleget tett a kötelezettségének, 
nem vétett hibát, vagy épp az okozati összefüggés fennállta vélelmezett. Az alábbiakban erre hozok néhány példát.

Azokban az esetekben, ahol az orvos ún. durva kezelési hibát vét, ${ }^{43}$ a betegnek nem kell bizonyítania ezen hiba és a bekövetkezett kár közötti okozati összefüggést, mert annak fennállását vélelmezik. ${ }^{44}$ Durva kezelési hiba alatt általánosságban alapvető szakmai szabályok érthetetlen, irracionális figyelmen kívül hagyását értjük, mellyel az orvos a biztonságos egészségügyi ellátást veszélyezteti és melyet egy orvos nem engedhetne meg magának. ${ }^{45}$ Ezekben az esetekben vélelmezik az orvos felelősségének fennállását, aki csak úgy mentesülhet, ha bizonyítani tudja, az okozati összefüggés hiányát, vagyis, hogy a sérelmet nem az ö hibája, hanem rajta kívül álló ok idézte elö.

Tipikus példa az eltérő bizonyítási teher tekintetében a szervezési hiányosságokból fakadó hibák köre. Például, ha egy mütétet nem egy kellö tapasztalattal rendelkező, hanem egy kezdő, tanuló orvos végez el és a beavatkozás során probléma adódik, vélelmezik, hogy a beavatkozást végző orvos nem kellő szakmai felkészültségéből fakadó tévedése idézte elő a problémát. ${ }^{46}$ Ilyenkor a kórháznak kell bizonyítania, hogy olyan szövődmény állt elő, mely akkor sem lett volna elkerülhető, ha a mütétet egy tapasztalt orvos végzi, vagy legalább felügyeli. Vagy szintén a szervezési hibák körébe vonható, ha a vizsgálatok, kezelés dokumentációja egyáltalán nem áll rendelkezésre vagy hiányos. Ilyen esetekben is az alperest terheli annak bizonyítása, hogy a szükséges vizsgálatokat elvégezték, a kezelés teljes mértékben korrekt volt. ${ }^{47}$

Szintén nem az általánosnak megfelelően alakul a bizonyítás terhe a tájékoztatási kötelezettség elmulasztásából eredő hibák esetén. Ilyenkor ugyanis az orvosnak kell kimentenie magát és igazolni, hogy a tájékoztatás megfelelő és korrekt volt, vagy, hogy a beteg a korrekt tájékoztatás megtörténte esetén is beleegyezett volna a kezelésbe. ${ }^{48}$

\section{Záró gondolatok}

Dolgozatomban a német egészségügyi ellátással kapcsolatos polgári jogi felelősség vizsgálatát és értékelését tüztem ki célul. A német szabályozással kapcsolatosan kialakult gondolataim az alábbiakban foglalhatóak össze.

Az egyik nagyon pozitív eredmény az alternatív vitarendezési mechanizmus beépítése az igényérvényesítésbe, melynek révén kordában tartható a bíróság elé kerülő igényérvényesítések száma. Ahogy fentebb kifejtettem ugyanis, a peres út mellett (azt megelőzően) lehetőség van ingyenesen és önkéntesen az orvosi kamara által létrehozott testületekhez fordulni, ahol nagy szaktudással rendelkező orvosok és jogászok, a peres útnál jóval gyorsabban ajánlanak megoldási lehetőséget a felek konfliktusára. Az esetek nagy többségében ez véglegesen megoldja a problémát, így a költséges is időigényes per elmaradhat. Úgy vélem, hogy egy ilyen országosan kiépülő, kellő népszerüséggel és bizalommal rendelkező hálózat Magyarország számára is megoldást jelenthetne az alternatív vitarendezési út népszerübbé tételére és a perek számának csökkentésére.

A másik pozitív vonás, amit kiemelnék a német rendszerrel kapcsolatban az a kártérítési összegek (elsősorban nem vagyoni kártérítés) kordában tartása. Ha megnézzük az USA problémáit egy jelentős részben arra vezethetők vissza, hogy a nem vagyoni kártérítési összegek durván megemelkedtek, így a kártérítési összegek eltúlzottá váltak. Ennek pedig súlyos következményei alakultak ki, mint például a felelősségbiztosítási piac krízise, a defenzív medicina, illetve egyes orvosi szakmák kiüresedése a túlzottan magas kockázatok miatt. Németországban viszont bár emelkedtek a nem vagyoni kártérítések, nem öltenek eltúlzott méreteket. Részben a szakbírók által kialakított és követett gyakorlatnak, részben a magas szintü szociális jóléti rendszernek (és a merőben más egészségbiztosítási rendszernek), 
részben pedig az eljárási költségekkel kapcsolatos, fentebb már részletesen kifejtett okokra vezethető vissza mindez.

Fontosnak tartom azt is megemlíteni, hogy a fentebb leírtaknak megfelelően Németországban kezelési szerződés formájában szabályozzák az orvos és beteg közötti viszonyt, melyet hazánk számára is fontos feladatnak tartok az új Polgári Törvénykönyv kodifikációja kapcsán. Összességében egy működőképes rendszer tárult elém a vizsgálat során. Tökéletesnek nem mondható, hiszen itt is megfigyelhetőek azok a tendenciák, amelyek a világ más területein is problémát jelentenek. Az egészségügyi ellátások igénybe vevői egyre inkább tudatos fogyasztóvá válnak és ezáltal sokkal gyakrabban kérdőjeleződik meg a kapott szolgáltatás minősége. Ennek következtében pedig megszaporodnak a nem megfelelőnek ítélt szolgáltatások kapcsán az igényérvényesítések, illetve emelkedő tendenciát mutatnak a kártérítésként megítélt összegek. Viszont a kiemelt pozitív vonásoknak köszönhetően véleményem szerint a német rendszer mégis megőrzi müködőképességét és nem alakultak ki olyan szélsőséges problémák, mint például az USA-ban.

\footnotetext{
${ }^{1}$ III. évfolyamos Ph.D hallgató, Debreceni Egyetem, Marton Géza Állam- és Jogtudományi Doktori Iskola

${ }^{2}$ Kaj ESSINGER: Medical liability: The alternative ways to court procedures, In: The ever growing challenges of medical liablity: national and European responses, Strasbourg, 2-3 June 2008, 43.o.

${ }^{3}$ Ennek minden hátrányos következményével együtt, így pl: elhúzódó perek, magas adminisztratív költségek

${ }^{4}$ Ennek előnyös vonásai: az eljárás leegyszerüsödik és felgyorsul, az adminisztratív költségek leredukálódnak, sokkal több beteg jut kompenzációhoz.

${ }^{5}$ Ahol nem lehet egyszerre a deliktuális és a kontrktuális szabályok alapján is kártérítést kérni

${ }^{6}$ Christiane Wendehorst: Compensation in the German health care sector; In: Jos DUTE, Michael FAURE, Helmut KozIol (editors): No-fault compensation in the helath care sector, Vienna, Springer Wien, 2004., 278. o.

7 Egyes német jogászok nem elkülönített csoportként tekintenek erre a felelősségre, hanem a deliktuális felelősség részeként

${ }^{8}$ Franz Michael PETRY: Medical Practicioners Liability in German law; In: Michael FAURE, Helmut KozIOL (eds.): Cases on medical malpractice in a perspective, Vienna, Springer-Verlag, 2001., 35. o.

${ }^{9}$ Uo. 36. o.

${ }^{10}$ Christiane Wendehorst: Compensation in the German health care sector; In: Jos DUTE, Michael FAURE, Helmut KozIol (editors): No-fault compensation in the helath care sector, Vienna, Springer Wien, 2004., 284. o.

${ }^{11}$ DósA Ágnes: Az orvos kártéritési felelössége, HVG ORAC, Budapest, 2004., 68. o.

12 Christiane Wendehorst: Compensation in the German health care sector; In: Jos Dute, Michael FAURE, Helmut KozIOl (editors): No-fault compensation in the helath care sector, Vienna, Springer Wien, 2004., 282. o. ${ }^{13}$ Uo. 263. o.

14 Franz Michael PETRY: Medical Practicioners Liability in German law; In: Michael FAURE, Helmut KOZIOL (eds.): Cases on medical malpractice in a perspective, Vienna, Springer-Verlag, 2001., 41. o.

${ }^{15}$ Franz Michael PETRY: Medical Practicioners Liability in German law; In: Michael FAURE, Helmut KozIOL (eds.): Cases on medical malpractice in a perspective, Vienna, Springer-Verlag, 2001., 43. o.

${ }^{16}$ A döntés végrehajtandó, ha a felek írásos alávetési nyilatkozatot tettek, ennek hiányában visszautasíthatják a végrehajtást.

${ }^{17}$ NÁDHÁzY Zsolt: A döntőbíráskodás magyarországi aspektusai, Munkaügyi Szemle, 2005, 11. szám, 51.o.

${ }^{18}$ Florida, Mediatoin in any civil actions $§ 44.301$

${ }^{19}$ NÁDHÁZY Zsolt: Alternatív vitafeloldás Európában-különös tekintettel a munkaügyi vitákra, Jogtudományi Közlöny, 2007 7-8. szám, 315. o.

${ }^{20}$ Herman NYs: The factual situation of medical liability int he member states of the Council of Europe, In: The ever growing challenges of medical liablity: national and European responses, Strasbourg, 2-3 June 2008., 21. o.

${ }^{21}$ Kaj EssINGER: Medical liability: The alternative ways to court procedures, In: The ever growing challenges of medical liablity: national and European responses, Strasbourg, 2-3 June 2008., 46. o.

${ }^{22}$ DósA Ágnes: Az orvos kártéritési felelőssége, HVG ORAC, Budapest, 2004., 41. o.

${ }^{23}$ Timothy STOLTZFUS Jost: The German approach to extrajudicial malpractice claims resolution, Ohio State Journal on Dispute Resolution, 1996, Vol. 11., 96. o.

${ }^{24}$ Azokban az esetekben, amikor a vitarendezés ezen módját választják a felek, mindössze az ügyek 15-20\%ában követi az egyeztetést peres út, az esetek döntő többségében per nélkül születik megfelelő döntés. Lásd: http://www.loc.gov/law/help/medical-malpractice-liability/germany.php (Letöltve: 2010. december 1.)
} 
${ }^{25}$ EUROPEAN COMMITTEE ON LEGAL CO-OPERATION: Report on medical liability in Council of Europe member states, Strasbourg, 7 March 2005., 16.o.

${ }^{26}$ Franz Michael PETRY: Medical Practicioners Liability in German law; In: Michael FAURE, Helmut KozIOL (eds.): Cases on medical malpractice in a perspective, Vienna, Springer-Verlag, 2001., 37. o.

${ }^{27}$ Miriam WIELAND: The economic analysys of German medical malpractice Law- with the emphasis ont he allocation of burden of proof, University of Hamburg, 2000/2001., 16. o.

${ }^{28}$ Franz Michael PETRY: Medical Practicioners Liability in German law; In: Michael FAURE, Helmut KozIOL (eds.): Cases on medical malpractice in a perspective, Vienna, Springer-Verlag, 2001., 17. o.

${ }^{29}$ EUROPEAN COMMITTEe ON LEGAL CO-OPERATION: Report on medical liability in Council of Europe member states, Strasbourg, 7 March 2005., 17. o.

${ }^{30}$ Franz Michael PETRY: Medical Practicioners Liability in German law; In: Michael FaURE, Helmut KozIOL (eds.): Cases on medical malpractice in a perspective, Vienna, Springer-Verlag, 2001.,

${ }^{31}$ Azokról a kockázatokról, melyek kifejezetten az adott kezeléshez vagy beavatkozáshoz kapcsolódnak (akkor is, ha ritka az előfordulásuk), azokról, amelyek jelentős károsodást vagy fogyatékosságot eredményezhetnek, illetve azokról is, amelyek egy laikus számára meglepőek lehetnek egy adott beavatkozással kapcsolatban.

32 Miriam WIELAND: The economic analysys of German medical malpractice Law- with the emphasis ont he allocation of burden of proof, University of Hamburg, 2000/2001., 17. o.

${ }^{33}$ Természetesen, ha például egy mütéti beavatkozás során lép fel komplikáció és életveszélybe kerül a beteg akkor az orvos túlléphet a beleegyezés határain és elvégezhet olyan beavatkozást is, amire a beteg beleegyezése eredetileg nem vonatkozott.

${ }^{34}$ EUROPEAN COMMITTEE ON LEGAL CO-OPERATION: Report on medical liability in Council of Europe member states, Strasbourg, 7 March 2005., 18. o.

${ }^{35}$ Franz Michael PeTRY: Medical Practicioners Liability in German law; In: Michael FaURe, Helmut KozIOL (eds.): Cases on medical malpractice in a perspective, Vienna, Springer-Verlag, 2001., 51. o.

${ }^{36}$ FÉzER Tamás: A nem vagyoni kártérités megitélése a külföldi jogalkotásban és jogalkalmazásban, Studia Iurisprudentiae Doctorandorum Miskolciensium, Tomus 5/1, 2004., 173. o.

${ }^{37}$ Timothy STOLTZFus Jost: The German approach to extrajudicial malpractice claims resolution, Ohio State Journal on Dispute Resolution, 1996, Vol. 11., 102. o.

${ }_{38} \mathrm{Pl}$. kétszer annyi nem vagyoni kártérítést követelt keresetében, mint amennyit jogosnak ítélt a bíróság.

${ }^{39}$ Ez nem vonatkozik az olyan esetekre, ha a megítélt összeg és a keresetben igényelt kártérítés között nincs számottevő eltérés. Lásd: http://www.loc.gov/law/help/medical-malpractice-liability/germany.php (Letöltve: 2010. december 1.)

${ }^{40}$ Miriam WIELAND: The economic analysys of German medical malpractice Law- with the emphasis ont he allocation of burden of proof, University of Hamburg, 2000/2001., 19. o.

${ }^{41}$ EUROPEAN COMMITTEE ON LEGAL CO-OPERATION: Report on medical liability in Council of Europe member states, Strasbourg, 7 March 2005., 18. o.

${ }_{42} \mathrm{http}: / /$ www.loc.gov/law/help/medical-malpractice-liability/germany.php

${ }^{43}$ gross negligence $=$ tudatos gondatlanság esetei

${ }^{44}$ Miriam WIELAND: The economic analysys of German medical malpractice Law- with the emphasis ont he allocation of burden of proof, University of Hamburg, 2000/2001., 23. o.

${ }^{45}$ Erre példaként szolgálhat egy olyan eset, melyben az orvos egy komoly mütéten átesett beteg megfigyelésének megszervezéséről nem gondoskodik, a páciensnél komplikáció lép fel, melynek következtében meghal.

${ }^{46}$ Franz Michael PETRY: Medical Practicioners Liability in German law; In: Michael FAURE, Helmut KozIOL (eds.): Cases on medical malpractice in a perspective, Vienna, Springer-Verlag, 2001., 45. o.

${ }^{47}$ Miriam WIELAND: The economic analysys of German medical malpractice Law- with the emphasis ont he allocation of burden of proof, University of Hamburg, 2000/2001., 30. o.

${ }^{48}$ EUROPEAN COMMITTEE ON LEGAL CO-OPERATION: Report on medical liability in Council of Europe member states, Strasbourg, 7 March 2005. 19. o. 